\title{
Physiological Growth Parameters of Rabi Rice (Oryza sativa L.) under Alternate Wetting and Drying Irrigation with Varied Nitrogen Levels
}

\author{
K. Sridhar ${ }^{1 *}$, A. Srinivas ${ }^{2}$, K. Avil Kumar ${ }^{3}$, T. Ramprakash ${ }^{4}$ and P. Raghuveer Rao ${ }^{5}$ \\ ${ }^{1}$ District Agricultural Advisory Transfer of Technology Centre, \\ Mahabubnagar, PJTSAU, India \\ ${ }^{2}$ Agricultural Research Institute Main Farm, PJTSAU Rajendranagar, Hyderabad \\ ${ }^{3}$ Water Technology Centre, ${ }^{4}$ AICRP on Weed Management, PJTSAU, Rajendranagar, \\ Hyderabad, India \\ ${ }^{5}$ Indian Institute of Rice Research, Rajendranagar, Hyderabad, India
}

*Corresponding author

\section{A B S T R A C T}

\section{Keywords}

Growth parameters,

Rabi rice,

Irrigation,

Nitrogen levels

Article Info

Accepted:

04 December 2018

Available Online:

10 January 2019
A field experiment was conducted during rabi 2016-17 and 2017-18 at Agricultural Research Institute Main Farm, Rajendranagar, Hyderabad, on a clay loam soil to study the effect of alternate wetting and drying irrigation on rabi rice under varied nitrogen levels. The experiment consisted of three irrigation regimes (recommended submergence of 2 to 5 $\mathrm{cm}$ water level as per crop growth stage, AWD irrigation of $5 \mathrm{~cm}$ when water level drops to $3 \mathrm{~cm}$ in water tube, AWD irrigation of $5 \mathrm{~cm}$ when water level drops to $5 \mathrm{~cm}$ in water tube) as main plot treatments and three nitrogen levels (120, 160 and $\left.200 \mathrm{~kg} \mathrm{~N} \mathrm{ha}^{-1}\right)$ as sub plot treatments laid out in split plot design with three replications. Significant improvement in the physiological growth parameters was observed with recommended submergence of 2 to $5 \mathrm{~cm}$ water level as per crop growth stage which was on par with AWD irrigation of $5 \mathrm{~cm}$ when water level drops to $3 \mathrm{~cm}$ in water tube. Among nitrogen levels, application of $200 \mathrm{~kg} \mathrm{~N} \mathrm{ha}^{-1}$ resulted in higher physiological growth parameters of Rabi Rice which was on par with application of $160 \mathrm{~kg} \mathrm{~N} \mathrm{ha}^{-1}$.

\section{Introduction}

Rice [Oryza sativa (L.)] is one of the most important staple food crops in the world. In Asia, more than two billion people are getting 60-70 per cent of their energy requirement from rice and its derived products. Among the rice growing countries, India has the largest area $(43.50 \mathrm{~m} \mathrm{ha})$ and it is the second largest producer $(163.51 \mathrm{~m} \mathrm{t})$ of rice next to China (203.14 $\mathrm{m} \mathrm{t}$ ) with an average productivity of
$3.76 \mathrm{t} \mathrm{ha}^{-1}$, though increasing marginally, but is still well below the world's average yield of $4.51 \mathrm{t} \mathrm{ha}^{-1}$ (www.ricestat.irri.org). In India, Telangana State is a key rice producing state with 10.46 lakh hectares with a production of 30.47 million tonnes (Statistical Year Book, Telangana, 2017). A huge amount of water is used for the rice irrigation under the conventional water management in lowland rice termed as "continuous deep flooding irrigation" consuming about 70 to 80 per cent 
of the total irrigated fresh water resources in the major part of the rice growing regions in Asia including India (Bouman and Tuong, 2001). Future predictions on water scarcity limiting agricultural production have estimated that by 2025 , about 15-20 million ha of Asia's irrigated rice fields will suffer from water shortage in the dry season especially since flood irrigated rice uses more than $45 \%$ of $90 \%$ of total freshwater used for agricultural purposes. Generally, rice consumes about 3000-5000 litres of water to produce one $\mathrm{kg}$ of rice, which is about two to three times more than to produce one kilogram of other cereals such as wheat or maize. Therefore, there is need to develop and adopt water saving methods in rice cultivation so that production and productivity levels are elevated despite the looming water crisis.

However, rice is very sensitive to water stress. Attempts to reduce water in rice production may result in yield reduction and may threaten food security. Several water-efficient irrigation strategies had been tested, advanced, applied and spread in different rice growing regions. One is the aerobic rice system where rice is grown like any other upland crop, resulting in substantial water savings but also in a significant penalty on grain yield, especially with the use of high-yielding irrigated varieties. Another important watersaving technique is alternate wetting and drying (AWD).

AWD is an irrigation technique where water is applied to the field a number of days after disappearance of ponded water. This is in contrast to the traditional irrigation practice of continuous flooding. This means that the rice fields are not kept continuously submerged but are allowed to dry intermittently during the rice growing stage. The underlying premise behind this irrigation technique is that the roots of the rice plant are still adequately supplied with water for some period even if there is currently no observable ponded water in the field. The AWD irrigation aims in reducing water input and increasing water productivity while maintaining grain yield (Bouman and Tuong, 2001). Singh et al., (1996) reported that, in India, the AWD irrigation approach can reduce water use by about 40-70 per cent compared to the traditional practice of continuous submergence, without a significant yield loss. The water availability in Telangana is limited during the rabi season thereby paddy is subjected to water stress. Alternate Wetting and Drying (AWD) is a suitable water saving irrigation technique.

Among nutrients, nitrogen is the most important limiting element in rice growth (Jayanthi et al., 2007). Limitation of this nutrient in the growth period causes reduction of dry matter accumulation and prevents grain filling and therefore increases the number of unfilled grains. Rice shows excellent response to nitrogen application, but the recovery of applied nitrogen is quite low approximately 31-40\% (Cassman et al., 2002).

Both water and nitrogen are most important inputs in rice production. The behaviour of soil nitrogen under wet soil conditions of lowland rice is markedly different from its behavior under dry soil conditions. Under flooded conditions, most nitrogen to be taken up by rice is in ammonium form. The practice of AWD results in periodic aerobic soil conditions, stimulating sequential nitrification and denitrification losses (Buresh and Haefele, 2010). Growing rice under AWD could consequently lead to a greater loss of applied fertilizer and soil nitrogen compared with that under submergence conditions. Water and nutrient may interact with each other to produce a coupling effect. Furthermore, if an interaction exists between water management practice and nitrogen rate, then the $\mathrm{N}$ input will have to be changed under AWD. The 
functional leaves, dry matter production and leaf area index, leaf area duration are the main growth factors which directly reflect the grain yield. Growth analysis parameters like crop growth rate (CGR), Relative growth rate (RGR) measures the increase in dry matter with a given amount of assimilatory material at a given point of time and net assimilation rate (NAR) is the net gain in total dry matter per unit leaf area per unit time. It was against this background that the field investigation was carried out to study the effect of alternate wetting and drying irrigation under varied nitrogen levels ion practices on physiological growth parameters of Rabi Rice.

\section{Materials and Methods}

A field experiment was conducted at Agricultural Research Institute Main Farm, Rajendranagar, Hyderabad, situated in Southern Telangana Zone of Telangana state at $17^{0} 32^{\prime}$ N Latitude, $78^{0} 39^{\prime}$ E Longitude with an altitude of $542.6 \mathrm{~m}$ above mean sea level. The soil of the experimental field was clay loam in texture, moderately alkaline in reaction, non-saline, low in organic carbon content, low in available nitrogen $(\mathrm{N})$, medium in available phosphorous $\left(\mathrm{P}_{2} \mathrm{O}_{5}\right)$ and potassium $\left(\mathrm{K}_{2} \mathrm{O}\right)$. The experiment consisted of three irrigation regimes (I) [(recommended submergence of 2 to $5 \mathrm{~cm}$ water level as per crop growth stage $\left(\mathrm{I}_{1}\right)$, AWD irrigation of 5 $\mathrm{cm}$ when water level drops to $3 \mathrm{~cm}$ in water tube $\left(\mathrm{I}_{2}\right)$, AWD irrigation of $5 \mathrm{~cm}$ when water level drops to $5 \mathrm{~cm}$ in water tube $\left.\left(\mathrm{I}_{3}\right)\right]$ as main plot treatments and three nitrogen levels $(\mathrm{N})$ [(120 kg N ha ${ }^{-1}\left(\mathrm{~N}_{1}\right), 160 \mathrm{~kg} \mathrm{~N}^{-1}\left(\mathrm{~N}_{2}\right)$ and $\left.200 \mathrm{~kg} \mathrm{~N} \mathrm{ha}^{-1}\left(\mathrm{~N}_{3}\right)\right]$ as sub plot treatments laid out in split plot design with three replications. Nitrogen was applied in the form of urea in three equal splits viz., $1 / 3^{\text {rd }}$ as basal, $1 / 3^{\text {rd }}$ at active tillering stage and $1 / 3^{\text {rd }}$ at panicle initiation stage. A uniform dose of $60 \mathrm{~kg} \mathrm{P}_{2} \mathrm{O}_{5}$ and $40 \mathrm{~kg} \mathrm{~K}_{2} \mathrm{O} \mathrm{ha}^{-1}$ was applied where entire phosphorus was applied as basal in the form of single super phosphate whereas, potassium was applied in the form of muriate of potash in two equal splits viz., as basal and top dressing at panicle initiation stage. The test variety used was KNM-118 which was transplanted at the age of 30 days at a spacing

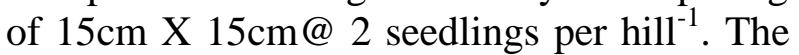
conventional flooding irrigation practice was followed in all the treatments till 15 days after transplanting for proper establishment of the crop. After 15 days after transplanting, the irrigation schedules were imposed as per the treatment requirements with the help of field water tube. The field water tube is made of plastic pipe having $40 \mathrm{~cm}$ length and $15 \mathrm{~cm}$ in diameter so that the water table is easily visible. The field tube also contains perforations of $0.5 \mathrm{~cm}$ in diameter and $2 \mathrm{~cm}$ apart, so that water can flow readily in and out of the tube. The field tube was hammered in to the soil in each net plot such that $15 \mathrm{~cm}$ protrudes above the soil surface. After installation, the soil from inside the field tube was removed so that the bottom of the tube is visible. Irrigation was applied to re flood the field to a water depth of $5 \mathrm{~cm}$ when the water level in the field tube dropped to a threshold level of about 3 or $5 \mathrm{~cm}$ depending on the treatment. Irrigation was withheld 10 days ahead of harvest. The size of the gross net plot size of $6.0 \mathrm{~m} \times 4.0 \mathrm{~m}$ and net plot size of 5.4 $\mathrm{m} \times 3.4 \mathrm{~m}$ was adopted in field experiment.

Leaf area $\left(\mathrm{cm}^{2}\right)$ of three randomly selected hills from each plot was estimated at tillering, panicle initiation, flowering and at harvest by using LICOR -3100 automatic leaf area meter and mean values were presented as $\mathrm{cm}^{2}$.

The leaf area index (LAI) is the ratio of leaf area per plant to the ground occupied by each plant (spacing). The LAI was calculated as given by Watson (1952).

$$
\text { LAI }=\frac{\text { Leaf area }\left(\mathrm{cm}^{2}\right)}{\text { Ground area }\left(\mathrm{cm}^{2}\right)}
$$


Leaf area duration (LAD) based on leaf area of individual plants from successive harvests was calculated as given by Hunt (1980).

$\operatorname{LAD}\left(\mathrm{dm}^{2}\right)=\frac{\left(\mathrm{LA}_{2}+\mathrm{LA} \mathrm{A}_{1}\right)\left(\mathrm{t}_{2}-\mathrm{t}_{1}\right)}{2}$

Where, $\mathrm{LA}_{2}$ and $\mathrm{LA}_{1}$ are leaf area index obtained at times $t_{2}$ and $t_{1}$ respectively. LAD represents mean LAD expressed in $\mathrm{dm}^{2}$ days.

The crop growth rate (CGR) at any instant time $(\mathrm{t})$ is defined as "the increase of plant material per unit of time" and is mathematically given by Watson (1958) as:

CGR $\left(\mathrm{g} \mathrm{m}^{-2}\right.$ day $\left.^{-1}\right)=\frac{\left(W_{2}-W_{1}\right)}{\left(t_{2}-t_{1}\right)} \times \frac{1}{P}$

Where, $\mathrm{W}_{2}$ and $\mathrm{W}_{1}$ are the values of dry weight of plant $(\mathrm{g})$ harvested from equal but separate areas of ground, $(\mathrm{P})$ at times $\mathrm{t}_{2}$ and $\mathrm{t}_{1}$ in days, respectively; and CGR is the mean crop growth rate expressed in $\mathrm{g} \mathrm{m}^{-2} \mathrm{day}^{-1}$.

The relative growth rate (RGR) of a plant at time instant $(t)$ is defined as the increase of plant material per unit of material initially present per unit of time and is mathematically expressed (Hunt, 1978) as shown below.

$\mathrm{RGR}=\frac{\ln \mathrm{W}_{2}-\ln \mathrm{W}_{1}}{\mathrm{t}_{2}-\mathrm{t}_{1}}$

Where, $\mathrm{W}_{1}$ and $\mathrm{W}_{2}$ are the dry weights $(\mathrm{g})$ at times $t_{1}$ and $t_{2}$ in days, respectively.

$\ln$ is natural logarithm. RGR is expressed in $g$ $\mathrm{g}^{-1}$ day $^{-1}$.

Net assimilation rate (NAR) or average assimilation rate defined as "the net increase in plant dry weight (photosynthesis minus respiration) per unit of assimilatory surface per unit time". Williams (1946) provided a convenient formula for the estimation of mean net assimilation rate (NAR) over a period of times as given below:

NAR $\left(\mathrm{g} \mathrm{m}^{-2}\right.$ day $^{-1}=\frac{\left(W_{2}-W_{1}\right)}{\left(t_{2}-t_{1}\right)} \times \frac{\left(\operatorname{In~LA} A_{2}-I n L A_{1}\right)}{\left(L_{2}-L_{1}\right)}$

Where, $\mathrm{W}_{2}$ and $\mathrm{W}_{1}$ are dry weights $(\mathrm{g})$ at times $t_{2}$ and $t_{1}$ in days, respectively. Likewise $L_{2}$ and $\mathrm{LA}_{1}$ are leaf area values in $\mathrm{m}^{2}$ measured at time $t_{2}$ and $t_{1}$, respectively and NAR represents the mean net assimilation rate expressed in $\mathrm{g} \mathrm{m}^{-2} \mathrm{day}^{-1}$; in is natural logarithm.

The weeds were managed using preemergence application of the recommended herbicide i.e., Oxadiargyl @ $87.5 \mathrm{~g} \mathrm{ha}^{-1}$ dissolved in water and mixed with soil and broadcasted uniformly 3 days after transplanting maintaining a thin film of water in the field and followed by one hand weeding at 35 days after transplanting. The data on various parameters studied during the course of investigation were statistically analyzed as suggested by Gomez and Gomez (1984).

\section{Results and Discussion}

\section{Leaf area}

The total leaf area of rice is a factor closely related to grain production because the total leaf area at flowering greatly affects the amount of photosynthates available to the panicle (Datta, 1981). Irrespective of treatments, leaf area hill $^{-1}$ of the rice crop increased up to panicle initiation stage, thereafter it decreased until harvest, which was due to senescence of the older leaves. Similar observations were found by Jayanti et al., (2007). Leaf area hill $^{-1}$ was not significantly influenced by irrigation regimes at tillering and harvest stages during both the years and in pooled means. At panicle initiation and flowering stages, leaf area hill ${ }^{-1}$ 
recorded was higher in recommended submergence of 2 to $5 \mathrm{~cm}$ water level as per crop growth stage $\left(\mathrm{I}_{1}\right)$ treatment but it was at par with AWD irrigation of $5 \mathrm{~cm}$ when water level drops to $3 \mathrm{~cm}$ in water tube $\left(\mathrm{I}_{2}\right)$, but both the treatments were statistically superior over AWD irrigation of $5 \mathrm{~cm}$ when water level drops to $5 \mathrm{~cm}$ in water tube $\left(\mathrm{I}_{3}\right)$. The increase in leaf area is due to adequate supply of irrigation water that created favourable moisture regimes and enabled the crop plant to grow rapidly by providing healthier micro climate for production and retention of higher leaf area for longer period. Similar results were also observed by Sandhu et al., (2012) and Kumar et al., (2013). The lowest leaf area was recorded with AWD irrigation of $5 \mathrm{~cm}$ when water level drops to $5 \mathrm{~cm}$ in water tube $\left(\mathrm{I}_{3}\right)$ at all the growth stages during both years and in pooled means. The reduction in leaf area with reduction in amount of irrigation water applied could be attributed to the reduction in leaf expansion due to stresses reported by Wopereis et al., (1996). Further, they found that leaf expansion is the most sensitive physiological process affected by water deficit in rice (Table 1).

Application of $200 \mathrm{~kg} \mathrm{~N}^{-1}\left(\mathrm{~N}_{3}\right)$ recorded significantly higher leaf area hill ${ }^{-1}$ over $120 \mathrm{~kg}$ $\mathrm{N} \mathrm{ha}^{-1}\left(\mathrm{~N}_{1}\right)$, but was on par with $160 \mathrm{~kg} \mathrm{~N} \mathrm{ha}^{-1}$ $\left(\mathrm{N}_{2}\right)$ at all growth stages of the crop except at harvest in both the years and in pooled means. This might be due to increased levels of $\mathrm{N}$ application in splits that synchronized with the nutritional demand of rice at all the stages and thus resulted in higher production of leaves and leaf area. This was supported by Sathiya and Ramesh (2009), Kumar et al., (2013) and Anil et al., (2014).

\section{Leaf area index}

Total leaf area per unit ground area is an important indicator of total source available to the plant for the production of photosynthates, which accumulate in the developing sink. The variation in LAI is an important physiological parameter that eventually determines crop yield because it influences the light interception by the crop canopy (Fageria et al., 2006). The average leaf area index (LAI) of the rice increased at a slower rate up to tillering and thereafter it increased steadily with the ontogeny of the plant reaching a peak value at panicle initiation, but there after it decreased gradually towards maturity due to senescence of leaves. The LAI of rice increases as crop growth advances and reaches a maximum at about heading or flowering (Yoshida, 1981). The development of leaf area index reflected a sigmoid pattern of the growth. There was no significant difference among irrigation regimes at tillering and at harvest during both the years and in pooled means. Irrigation maintained at recommended submergence of 2 to $5 \mathrm{~cm}$ water level as per crop growth stage $\left(\mathrm{I}_{1}\right)$ recorded higher leaf area index but it was at par with AWD irrigation of $5 \mathrm{~cm}$ when water level drops to $3 \mathrm{~cm}$ in water tube $\left(\mathrm{I}_{2}\right)$, but both the treatments were statistically superior over AWD irrigation of $5 \mathrm{~cm}$ when water level drops to 5 $\mathrm{cm}$ in water tube $\left(\mathrm{I}_{3}\right)$. Lower leaf area index under delayed irrigations could be due to development of water stress in plants, resulting in reduced cellular growth lowering down of leaf water potential, closure of stomata and decline in radiation use efficiency. The reduction in LAI with reduction in amount of irrigation water applied might be attributed to the reduction in leaf expansion due to water stress reported by Wopereis et al., (1996). The results are corroborated to the findings of Sandhu et al., (2012) and Chowdhury et al., (2014) (Table 2).

Application of $200 \mathrm{~kg} \mathrm{~N} \mathrm{ha}^{-1}\left(\mathrm{~N}_{3}\right)$ recorded significantly higher leaf area index over 120 $\mathrm{kg} \mathrm{N} \mathrm{ha}^{-1}\left(\mathrm{~N}_{1}\right)$, but was on par with $160 \mathrm{~kg} \mathrm{~N}$ $\mathrm{ha}^{-1}\left(\mathrm{~N}_{2}\right)$ at all growth stages of the crop except at harvest in both the years and in pooled means. This might be due to favorable effect of nitrogen on cell division and tissue 
organization that ultimately improved tiller formation leading to higher LAI. Several researchers have also observed similar results in rice crop (Huang et al., 2008, Ghosh et al., 2013 and Chowdhury et al., 2014). The most important role of $\mathrm{N}$ in the plant is its presence in the structure of protein, the most important building substance from which the living material or protoplasm of every cell is made. In addition, nitrogen is also found in chlorophyll, the green colouring matter of leaves. Chlorophyll enables the plant to transfer energy from sunlight by photosynthesis. Therefore, nitrogen supply to the plant will influence the amount of protein, protoplasm and chlorophyll formed. Inturn, this influences cell size and leaf area and photosynthetic activity.

\section{Leaf area duration}

Leaf area duration (LAD) measures the ability of the plant to produce and maintain leaf area. Leaf area duration was low between 0-30 DAT, thereafter it increased linearly and attained peak values between 60-90 DAT and later declined towards harvest. Leaf area duration of rice was not influenced significantly due to irrigation regimes between 0-30 DAT. The LAD between 30-60 and 6090 DAT was markedly higher with recommended submergence of 2 to $5 \mathrm{~cm}$ water level as per crop growth stage $\left(\mathrm{I}_{1}\right)$ but it was at par with AWD irrigation of $5 \mathrm{~cm}$ when water level drops to $3 \mathrm{~cm}$ in water tube $\left(\mathrm{I}_{2}\right)$, but both the treatments were statistically superior over AWD irrigation of $5 \mathrm{~cm}$ when water level drops to $5 \mathrm{~cm}$ in water tube $\left(\mathrm{I}_{3}\right)$ at $30-60,60-90$ DAT and 90DAT-harvest in pooled means, respectively. Growing plants suffered due to moisture stress, hence plants were unable to extract more water and nutrients from deeper layers of soil under moisture deficit conditions which ultimately led to poor number of tillers as well as leaf area $\mathrm{m}^{-2}$. These results are substantiated with the observations made by several researchers (Sandhu et al., 2012,
Chowdhury et al., 2014 and Kumar et al., 2014). Application of $200 \mathrm{~kg} \mathrm{~N} \mathrm{ha}^{-1}\left(\mathrm{~N}_{3}\right)$ recorded significantly higher leaf area duration over $120 \mathrm{~kg} \mathrm{~N} \mathrm{ha}^{-1}\left(\mathrm{~N}_{1}\right)$, but was on par with $160 \mathrm{~kg} \mathrm{~N} \mathrm{ha}^{-1}\left(\mathrm{~N}_{2}\right)$ at all growth stages of the crop except at harvest in both the years and in pooled means (Table 3 ).

\section{Crop growth rate}

As crop growth rate represents dry matter production per unit area over a period of time and it is considered as the most critical and meaningful growth function. The mean crop growth rate (CGR) was slow between 0-30 DAT, then increased linearly between 30-60 DAT, thereafter increasing slowly between 60 and 90 DAT and finally it decreased sharply towards harvest. Lower CGR in the initial growth stage appears to be mainly due to low leaf area, while higher CGR at flowering and grain development stages may be due to higher LAI and decrease in CGR towards maturity may be attributed to decrease in leaf area as a result of senescence of leaves. The crop growth rate was not influenced significantly by irrigation regimes between except at 30-60 DAT during both the years of study and in pooled means. Irrigation maintained at recommended submergence of $2-5 \mathrm{~cm}$ water level as per crop growth stage $\left(\mathrm{I}_{1}\right)$ registered significantly higher crop growth rate at 30-60 DAT of rice during both the years. The crop growth rate was not influenced significantly by nitrogen levels except at 0-30 DAT where significantly higher crop growth rate was recorded with application of $200 \mathrm{~kg} \mathrm{~N} \mathrm{ha}^{-1}$ which was however on par with $160 \mathrm{~kg} \mathrm{~N} \mathrm{ha}^{-1}$ during both the years (Table 4).

\section{Relative growth rate}

The rate at which a plant incorporates new material of dry matter accumulation into its sink is measured by RGR and is expressed in $\mathrm{g} \mathrm{g}^{-1}$ day $^{-1}$. 
Table.1 Leaf area $\left(\mathrm{cm}^{2}\right.$ hill $\left.^{-1}\right)$ of rice as influenced by alternate wetting and drying irrigation and nitrogen levels during rabi 2016, 2017 and pooled means

\begin{tabular}{|c|c|c|c|c|c|c|c|c|c|c|c|c|}
\hline \multirow[t]{3}{*}{ Treatments } & \multicolumn{12}{|c|}{ Leaf area $\left(\mathrm{cm}^{2} \mathrm{hill}^{-1}\right)$} \\
\hline & \multicolumn{3}{|c|}{ Tillering } & \multicolumn{3}{|c|}{ Panicle Initiation } & \multicolumn{3}{|c|}{ Flowering } & \multicolumn{3}{|c|}{ Harvest } \\
\hline & 2016 & 2017 & Pooled & 2016 & 2017 & Pooled & 2016 & 2017 & Pooled & 2016 & 2017 & Pooled \\
\hline \multicolumn{13}{|l|}{ Irrigation regimes (I) } \\
\hline $\mathbf{I}_{2}$ & 321.8 & 333.1 & 327.4 & 823.9 & 831.8 & 827.8 & 701.1 & 704.0 & 702.6 & 353.2 & 362.7 & 358.0 \\
\hline $\mathbf{I}_{3}$ & 322.5 & 333.3 & 327.9 & 817.6 & 825.8 & 821.7 & 675.6 & 683.9 & 679.7 & 349.4 & 359.9 & 354.6 \\
\hline S.Em \pm & 1.73 & 3.09 & 2.38 & 2.47 & 3.51 & 1.67 & 5.97 & 4.39 & 5.08 & 1.92 & 2.65 & 2.13 \\
\hline \multicolumn{13}{|l|}{ Nitrogen levels (N) } \\
\hline $\mathrm{N}_{1}-120 \mathrm{~kg} \mathrm{ha}^{-1}$ & 313.3 & 324.1 & 318.7 & 821.6 & 829.1 & 825.4 & 687.5 & 691.4 & 689.4 & 352.2 & 361.8 & 357.0 \\
\hline$N_{2}-160 \mathrm{~kg} \mathrm{ha}^{-1}$ & 325.6 & 337.1 & 331.4 & 823.6 & 830.3 & 826.9 & 694.5 & 700.6 & 697.6 & 352.6 & 360.6 & 356.6 \\
\hline $\mathrm{N}_{3}-200 \mathrm{~kg} \mathrm{ha}^{-1}$ & 329.0 & 338.8 & 333.9 & 828.4 & 838.6 & 833.5 & 708.4 & 709.3 & 708.8 & 353.9 & 363.0 & 358.4 \\
\hline S.Em. \pm & 2.14 & 2.03 & 2.07 & 2.38 & 3.71 & 2.76 & 7.16 & 5.84 & 6.04 & 1.37 & 2.87 & 1.82 \\
\hline C.D. at 5\% & 4.7 & 4.4 & 4.5 & 5.2 & 8.1 & 6.0 & 15.6 & 12.7 & 13.2 & NS & NS & NS \\
\hline
\end{tabular}

$\mathrm{I}_{1}$-Recommended submergence of 2-5 $\mathrm{cm}$ water level as per crop growth stage

$\mathrm{I}_{2}$-AWD irrigation of $5 \mathrm{~cm}$ when water level falls below $3 \mathrm{~cm}$ from soil surface in perforated pipe

$\mathrm{I}_{3}$-AWD irrigation of $5 \mathrm{~cm}$ when water level falls below $5 \mathrm{~cm}$ from soil surface in perforated pipe 
Table.2 Leaf area index of rice as influenced by alternate wetting and drying irrigation and nitrogen levels during rabi 2016,2017 and pooled means

\begin{tabular}{|c|c|c|c|c|c|c|c|c|c|c|c|c|}
\hline \multirow[t]{3}{*}{ Treatments } & \multicolumn{12}{|c|}{ Leaf area index } \\
\hline & \multicolumn{3}{|c|}{ Tillering } & \multicolumn{3}{|c|}{ Panicle Initiation } & \multicolumn{3}{|c|}{ Flowering } & \multicolumn{3}{|c|}{ Harvest } \\
\hline & 2016 & 2017 & Pooled & 2016 & 2017 & Pooled & 2016 & 2017 & Pooled & 2016 & 2017 & Pooled \\
\hline \multicolumn{13}{|l|}{ Irrigation regimes (I) } \\
\hline $\mathbf{I}_{1}$ & 1.43 & 1.48 & 1.46 & 3.69 & 3.73 & 3.71 & 3.17 & 3.17 & 3.17 & 1.58 & 1.61 & 1.59 \\
\hline $\mathbf{I}_{2}$ & 1.43 & 1.48 & 1.45 & 3.66 & 3.69 & 3.67 & 3.11 & 3.12 & 3.12 & 1.56 & 1.61 & 1.59 \\
\hline $\mathbf{I}_{3}$ & 1.43 & 1.48 & 1.45 & 3.63 & 3.67 & 3.65 & 3.00 & 3.03 & 3.02 & 1.55 & 1.59 & 1.57 \\
\hline S.Em士 & 0.007 & 0.013 & 0.01 & 0.01 & 0.01 & 0.007 & 0.02 & 0.01 & 0.02 & 0.008 & 0.01 & 0.009 \\
\hline C.D. at $5 \%$ & NS & NS & NS & 0.03 & 0.04 & 0.02 & 0.07 & 0.05 & 0.06 & NS & NS & NS \\
\hline \multicolumn{13}{|l|}{ Nitrogen levels $(\mathrm{N})$} \\
\hline $\mathrm{N}_{1}-120 \mathrm{~kg} \mathrm{ha}^{-1}$ & 1.39 & 1.44 & 1.41 & 3.65 & 3.68 & 3.66 & 3.05 & 3.07 & 3.06 & 1.56 & 1.60 & 1.58 \\
\hline$N_{2}-160 \mathrm{~kg} \mathrm{ha}^{-1}$ & 1.44 & 1.49 & 1.47 & 3.66 & 3.69 & 3.67 & 3.08 & 3.11 & 3.10 & 1.56 & 1.60 & 1.58 \\
\hline $\mathrm{N}_{3}-200 \mathrm{~kg} \mathrm{ha}^{-1}$ & 1.46 & 1.50 & 1.48 & 3.68 & 3.72 & 3.70 & 3.14 & 3.15 & 3.15 & 1.57 & 1.61 & 1.59 \\
\hline 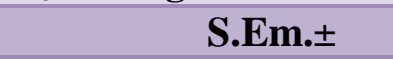 & 0.009 & 0.009 & 0.009 & 0.01 & 0.01 & 0.01 & 0.03 & 0.02 & 0.02 & 0.006 & 0.01 & 0.008 \\
\hline C.D. at $5 \%$ & 0.02 & 0.01 & 0.02 & 0.02 & 0.03 & 0.02 & 0.06 & 0.05 & 0.05 & NS & NS & NS \\
\hline Interactions & NS & NS & NS & NS & NS & NS & NS & NS & NS & NS & NS & NS \\
\hline
\end{tabular}

$\mathrm{I}_{1}$-Recommended submergence of 2-5 $\mathrm{cm}$ water level as per crop growth stage

$\mathrm{I}_{2}$-AWD irrigation of $5 \mathrm{~cm}$ when water level falls below $3 \mathrm{~cm}$ from soil surface in perforated pipe

$\mathrm{I}_{3}$-AWD irrigation of $5 \mathrm{~cm}$ when water level falls below $5 \mathrm{~cm}$ from soil surface in perforated pipe 
Table. 3 Leaf area duration ( $\mathrm{dm}^{2}$ days) of rice as influenced by alternate wetting and drying irrigation and nitrogen levels during rabi 2016, 2017 and pooled means

\begin{tabular}{|c|c|c|c|c|c|c|c|c|c|c|c|c|}
\hline \multirow[t]{3}{*}{ Treatments } & \multicolumn{12}{|c|}{ Leaf area duration $\left(\mathrm{dm}^{2}\right.$ days $)$} \\
\hline & \multicolumn{3}{|c|}{ 0-30 DAT } & \multicolumn{3}{|c|}{ 30-60DAT } & \multicolumn{3}{|c|}{ 60-90DAt } & \multicolumn{3}{|c|}{ 90-Harvest } \\
\hline & 2016 & 2017 & Pooled & 2016 & 2017 & Pooled & 2016 & 2017 & Pooled & 2016 & 2017 & Pooled \\
\hline \multicolumn{13}{|l|}{ Irrigation regimes (I) } \\
\hline $\mathbf{I}_{1}$ & 21.58 & 22.24 & 21.91 & 77.05 & 78.49 & 77.77 & 103.05 & 103.59 & 103.32 & 23.84 & 23.37 & 23.61 \\
\hline $\mathbf{I}_{2}$ & 21.45 & 22.20 & 21.82 & 76.37 & 77.65 & 77.01 & 101.66 & 102.38 & 102.02 & 23.19 & 22.75 & 22.97 \\
\hline $\mathbf{I}_{3}$ & 21.50 & 22.21 & 21.85 & 76.00 & 77.04 & 76.52 & 99.54 & 100.64 & 100.09 & 21.75 & 21.60 & 21.68 \\
\hline S.Em \pm & 0.11 & 0.20 & 0.15 & 0.12 & 0.35 & 0.15 & 0.45 & 0.22 & 0.28 & 0.44 & 0.42 & 0.42 \\
\hline C.D. at 5\% & NS & NS & NS & 0.35 & 0.98 & 0.42 & 1.25 & 0.61 & 0.78 & 1.22 & 1.17 & 1.16 \\
\hline \multicolumn{13}{|l|}{ Nitrogen levels $(\mathbf{N})$} \\
\hline $\mathrm{N}_{1}-120 \mathrm{~kg} \mathrm{ha}^{-1}$ & 20.88 & 21.60 & 21.24 & 75.65 & 76.88 & 76.27 & 100.60 & 101.36 & 100.98 & 22.35 & 21.96 & 22.16 \\
\hline$N_{2}-160 \mathrm{~kg} \mathrm{ha}^{-1}$ & 21.71 & 22.47 & 22.09 & 76.62 & 77.82 & 77.22 & 101.20 & 102.05 & 101.63 & 22.85 & 22.67 & 22.76 \\
\hline $\mathrm{N}_{3}-200 \mathrm{~kg} \mathrm{ha}^{-1}$ & 21.93 & 22.58 & 22.25 & 77.15 & 78.49 & 77.82 & 102.45 & 103.19 & 102.82 & 23.59 & 23.08 & 23.33 \\
\hline S.Em. \pm & 0.14 & 0.13 & 0.13 & 0.20 & 0.34 & 0.24 & 0.54 & 0.56 & 0.50 & 0.50 & 0.51 & 0.46 \\
\hline C.D. at 5\% & 0.31 & 0.29 & 0.30 & 0.45 & 0.75 & 0.53 & 1.18 & 1.22 & 1.09 & NS & NS & NS \\
\hline Interactions & NS & NS & NS & NS & NS & NS & NS & NS & NS & NS & NS & NS \\
\hline
\end{tabular}

$\mathrm{I}_{1}$-Recommended submergence of 2-5 $\mathrm{cm}$ water level as per crop growth stage

$\mathrm{I}_{2}$-AWD irrigation of $5 \mathrm{~cm}$ when water level falls below $3 \mathrm{~cm}$ from soil surface in perforated pipe

$\mathrm{I}_{3}$-AWD irrigation of $5 \mathrm{~cm}$ when water level falls below $5 \mathrm{~cm}$ from soil surface in perforated pipe 
Table.4 Crop growth rate $\left(\mathrm{g} \mathrm{m}^{-2} \mathrm{day}^{-1}\right)$ of rice as influenced by alternate wetting and drying irrigation and nitrogen levels during rabi 2016, 2017 and pooled means

\begin{tabular}{|c|c|c|c|c|c|c|c|c|c|c|c|c|}
\hline \multirow[t]{3}{*}{ Treatments } & \multicolumn{12}{|c|}{ Crop growth rate $\left(\mathrm{g} \mathrm{m}^{-2}\right.$ day $\left.^{-1}\right)$} \\
\hline & \multicolumn{3}{|c|}{ 0-30 DAT } & \multicolumn{3}{|c|}{ 30-60DAT } & \multicolumn{3}{|c|}{ 60-90DAT } & \multicolumn{3}{|c|}{ 90-Harvest } \\
\hline & 2016 & 2017 & Pooled & 2016 & 2017 & Pooled & 2016 & 2017 & Pooled & 2016 & 2017 & Pooled \\
\hline \multicolumn{13}{|l|}{ Irrigation regimes (I) } \\
\hline $\mathbf{I}_{1}$ & 4.82 & 5.13 & 4.98 & 14.52 & 14.33 & 14.42 & 20.86 & 21.38 & 21.12 & 2.95 & 2.72 & 2.83 \\
\hline $\mathbf{I}_{2}$ & 4.73 & 5.14 & 4.94 & 14.38 & 14.13 & 14.26 & 20.88 & 21.34 & 21.11 & 2.75 & 2.66 & 2.71 \\
\hline $\mathbf{I}_{3}$ & 4.65 & 5.05 & 4.85 & 14.14 & 14.01 & 14.07 & 20.53 & 21.02 & 20.77 & 2.50 & 1.86 & 2.23 \\
\hline S.Em \pm & 0.04 & 0.04 & 0.04 & 0.08 & 0.05 & 0.06 & 0.11 & 0.12 & 0.11 & 0.19 & 0.29 & 0.21 \\
\hline C.D. at 5\% & NS & NS & NS & 0.24 & 0.15 & 0.17 & NS & NS & NS & NS & NS & NS \\
\hline \multicolumn{13}{|l|}{ Nitrogen levels $(\mathrm{N})$} \\
\hline $\mathrm{N}_{1}-120 \mathrm{~kg} \mathrm{ha}^{-1}$ & 4.67 & 5.02 & 4.84 & 14.36 & 14.13 & 14.25 & 20.67 & 21.17 & 20.92 & 2.76 & 2.39 & 2.58 \\
\hline$N_{2}-160 \mathrm{~kg} \mathrm{ha}^{-1}$ & 4.72 & 5.11 & 4.89 & 14.35 & 14.16 & 14.26 & 20.70 & 21.26 & 20.98 & 2.84 & 2.43 & 2.63 \\
\hline $\mathrm{N}_{3}-200 \mathrm{~kg} \mathrm{ha}^{-1}$ & 4.82 & 5.20 & 5.01 & 14.32 & 14.17 & 14.25 & 20.90 & 21.30 & 21.10 & 2.71 & 2.42 & 2.56 \\
\hline S.Em. \pm & 0.04 & 0.04 & 0.03 & 0.06 & 0.06 & 0.04 & 0.13 & 0.11 & 0.11 & 0.14 & 0.16 & 0.13 \\
\hline C.D. at 5\% & 0.10 & 0.10 & 0.07 & NS & NS & NS & NS & NS & NS & NS & NS & NS \\
\hline Interactions & NS & NS & NS & NS & NS & NS & NS & NS & NS & NS & NS & NS \\
\hline
\end{tabular}

$\mathrm{I}_{1}$-Recommended submergence of 2-5 $\mathrm{cm}$ water level as per crop growth stage

$\mathrm{I}_{2}$-AWD irrigation of $5 \mathrm{~cm}$ when water level falls below $3 \mathrm{~cm}$ from soil surface in perforated pipe

$\mathrm{I}_{3}$-AWD irrigation of $5 \mathrm{~cm}$ when water level falls below $5 \mathrm{~cm}$ from soil surface in perforated pipe 
Table.5 Relative growth rate $\left(\mathrm{g} \mathrm{g}^{-1} \mathrm{day}^{-1}\right)$ of rice as influenced by alternate wetting and drying irrigation and nitrogen levels during rabi 2016, 2017 and pooled means

\begin{tabular}{|c|c|c|c|c|c|c|c|c|c|c|c|c|}
\hline \multirow[t]{3}{*}{ Treatments } & \multicolumn{12}{|c|}{ Relative growth rate $\left(\mathrm{g} \mathrm{g}^{-1}\right.$ day $\left.^{-1}\right)$} \\
\hline & \multicolumn{3}{|c|}{ 0-30 DAT } & \multicolumn{3}{|c|}{ 30-60DAT } & \multicolumn{3}{|c|}{ 60-90DAT } & \multicolumn{3}{|c|}{ 90-Harvest } \\
\hline & 2016 & 2017 & Pooled & 2016 & 2017 & Pooled & 2016 & 2017 & Pooled & 2016 & 2017 & Pooled \\
\hline \multicolumn{13}{|c|}{ Irrigation regimes (I) } \\
\hline $\mathbf{I}_{1}$ & 0.0687 & 0.0730 & 0.0708 & 0.0266 & 0.0240 & 0.0253 & 0.0198 & 0.0184 & 0.0191 & 0.0043 & 0.0045 & 0.0044 \\
\hline $\mathbf{I}_{2}$ & 0.0647 & 0.0684 & 0.0666 & 0.0225 & 0.0202 & 0.0213 & 0.0185 & 0.0176 & 0.0181 & 0.0036 & 0.0038 & 0.0037 \\
\hline $\mathbf{I}_{3}$ & 0.0568 & 0.0604 & 0.0586 & 0.0218 & 0.0191 & 0.0204 & 0.0154 & 0.0148 & 0.0151 & 0.0033 & 0.0036 & 0.0035 \\
\hline S.Em \pm & 0.0004 & 0.0003 & 0.0004 & 0.0008 & 0.0006 & 0.0007 & 0.0006 & 0.0004 & 0.0005 & 0.0001 & 0.0001 & 0.0001 \\
\hline C.D. at 5\% & NS & NS & NS & 0.0022 & 0.0016 & 0.0019 & NS & NS & NS & NS & NS & NS \\
\hline \multicolumn{13}{|l|}{ Nitrogen levels $(\mathbf{N})$} \\
\hline$N_{1}-120 \mathrm{~kg} \mathrm{ha}^{-1}$ & 0.0619 & 0.0660 & 0.0640 & 0.0223 & 0.0197 & 0.0210 & 0.0167 & 0.0157 & 0.0165 & 0.0033 & 0.0035 & 0.0034 \\
\hline$N_{2}-160 \mathrm{~kg} \mathrm{ha}^{-1}$ & 0.0626 & 0.0666 & 0.0646 & 0.0227 & 0.0206 & 0.0217 & 0.0174 & 0.0163 & 0.0167 & 0.0039 & 0.0041 & 0.0041 \\
\hline $\mathrm{N}_{3}-200 \mathrm{~kg} \mathrm{ha}^{-1}$ & 0.0658 & 0.0691 & 0.0674 & 0.0259 & 0.0230 & 0.0244 & 0.0196 & 0.0187 & 0.0192 & 0.0040 & 0.0043 & 0.0044 \\
\hline S.Em. \pm & 0.0003 & 0.0002 & 0.0003 & 0.0005 & 0.0003 & 0.0004 & 0.0003 & 0.0004 & 0.0003 & 0.0001 & 0.0001 & 0.0001 \\
\hline C.D. at 5\% & 0.0006 & 0.0004 & 0.0006 & NS & NS & NS & NS & NS & NS & NS & NS & NS \\
\hline Interactions & NS & NS & NS & NS & NS & NS & NS & NS & NS & NS & NS & NS \\
\hline
\end{tabular}

$\mathrm{I}_{1}$-Recommended submergence of $2-5 \mathrm{~cm}$ water level as per crop growth stage

$\mathrm{I}_{2}$-AWD irrigation of $5 \mathrm{~cm}$ when water level falls below $3 \mathrm{~cm}$ from soil surface in perforated pipe

$\mathrm{I}_{3}$-AWD irrigation of $5 \mathrm{~cm}$ when water level falls below $5 \mathrm{~cm}$ from soil surface in perforated pipe 
Table.6 Net assimilation rate $\left(\mathrm{g} \mathrm{m}^{-2} \mathrm{day}^{-1}\right)$ of rice as influenced by alternate wetting and drying irrigation and nitrogen levels during rabi 2016, 2017 and pooled means

\begin{tabular}{|c|c|c|c|c|c|c|c|c|c|c|c|c|}
\hline \multirow[t]{3}{*}{ Treatments } & \multicolumn{12}{|c|}{ Net assimilation rate $\left(\mathrm{g} \mathrm{m}^{-2}\right.$ day $\left.^{-1}\right)$} \\
\hline & \multicolumn{3}{|c|}{ 0-30 DAT } & \multicolumn{3}{|c|}{ 30-60DAT } & \multicolumn{3}{|c|}{ 60-90DAT } & \multicolumn{3}{|c|}{ 90-Harvest } \\
\hline & 2016 & 2017 & Pooled & 2016 & 2017 & Pooled & 2016 & 2017 & Pooled & 2016 & 2017 & Pooled \\
\hline \multicolumn{13}{|c|}{ Irrigation regimes (I) } \\
\hline $\mathbf{I}_{1}$ & 0.1866 & 0.1902 & 0.1884 & 0.0312 & 0.0293 & 0.0303 & 0.0520 & 0.0523 & 0.0522 & 0.0102 & 0.0093 & 0.0097 \\
\hline $\mathbf{I}_{2}$ & 0.1830 & 0.1922 & 0.1881 & 0.0311 & 0.0291 & 0.0301 & 0.0479 & 0.0484 & 0.0481 & 0.0098 & 0.0093 & 0.0093 \\
\hline $\mathbf{I}_{3}$ & 0.1801 & 0.1877 & 0.1839 & 0.0302 & 0.0283 & 0.0293 & 0.0462 & 0.0469 & 0.0465 & 0.0098 & 0.0068 & 0.0085 \\
\hline S.Em \pm & 0.0022 & 0.0024 & 0.0023 & 0.0001 & 0.0003 & 0.0001 & 0.0001 & 0.0003 & 0.0002 & 0.0006 & 0.0010 & 0.0007 \\
\hline C.D. at 5\% & NS & NS & NS & 0.0002 & 0.0002 & 0.0004 & 0.0004 & 0.0008 & 0.0006 & NS & NS & NS \\
\hline \multicolumn{13}{|l|}{ Nitrogen levels $(\mathrm{N})$} \\
\hline $\mathrm{N}_{1}-120 \mathrm{~kg} \mathrm{ha}^{-1}$ & 0.1800 & 0.1863 & 0.1832 & 0.0294 & 0.0276 & 0.0285 & 0.0481 & 0.0484 & 0.0482 & 0.0095 & 0.0084 & 0.0090 \\
\hline$N_{2}-160 \mathrm{~kg} \mathrm{ha}^{-1}$ & 0.1826 & 0.1903 & 0.1864 & 0.0308 & 0.0289 & 0.0298 & 0.0485 & 0.0493 & 0.0489 & 0.0102 & 0.0085 & 0.0093 \\
\hline $\mathrm{N}_{3}-200 \mathrm{~kg} \mathrm{ha}^{-1}$ & 0.1880 & 0.1935 & 0.1908 & 0.0323 & 0.0302 & 0.0312 & 0.0495 & 0.0499 & 0.0497 & 0.0100 & 0.0085 & 0.0093 \\
\hline S.Em. \pm & 0.0021 & 0.0025 & 0.0019 & 0.0002 & 0.0002 & 0.0002 & 0.0005 & 0.0004 & 0.0004 & 0.0005 & 0.0006 & 0.0004 \\
\hline C.D. at $5 \%$ & 0.0057 & 0.0055 & 0.0052 & 0.0015 & 0.0014 & 0.0014 & NS & NS & NS & NS & NS & NS \\
\hline Interactions & NS & NS & NS & NS & NS & NS & NS & NS & NS & NS & NS & NS \\
\hline
\end{tabular}

$\mathrm{I}_{1}$-Recommended submergence of $2-5 \mathrm{~cm}$ water level as per crop growth stage

$\mathrm{I}_{2}$-AWD irrigation of $5 \mathrm{~cm}$ when water level falls below $3 \mathrm{~cm}$ from soil surface in perforated pipe

$\mathrm{I}_{3}$-AWD irrigation of $5 \mathrm{~cm}$ when water level falls below $5 \mathrm{~cm}$ from soil surface in perforated pipe 
Mean relative growth rate was very high between 0-30 DAT thereafter it decreased gradually between 30 and 60 and 60-90 DAT and it continued to decrease appreciably towards harvest. The decrease in RGR is attributed for several reasons viz., non photosynthetic biomass increases, the top leaves of a plant began to shade lower leaves and soil nutrients become limiting (Table 5).

Overall respiration scales with total biomass, but photosynthesis only scales with photosynthetic biomass and as a result of which biomass accumulates more slowly as total biomass increases (Wopereis et al., 1996). Among irrigation regimes, there was no significant difference in relative growth rate between 0-30 DAT, 60-90 DAT and 90 DAT- harvest during both the years and in pooled means. However between 30-60 DAT, recommended submergence of 2 to $5 \mathrm{~cm}$ water level as per crop growth stage $\left(\mathrm{I}_{1}\right)$ but it was at par with AWD irrigation of $5 \mathrm{~cm}$ when water level drops to $3 \mathrm{~cm}$ in water tube $\left(\mathrm{I}_{2}\right)$, but both the treatments were statistically superior over AWD irrigation of $5 \mathrm{~cm}$ when water level drops to $5 \mathrm{~cm}$ in water tube $\left(\mathrm{I}_{3}\right)$. Plants suffered due to moisture stress with irrigation at 5 DADPW hence, plants were unable to extract adequate water and nutrients from soil under moisture deficit conditions which ultimately led to poor dry matter accumulation (Sandhu et al., 2012).

Between 0-30 DAT, significantly higher relative growth rate was observed with application of $200 \mathrm{~kg} \mathrm{~N} \mathrm{ha}{ }^{-1}$ which was however on par with $160 \mathrm{~kg} \mathrm{~N} \mathrm{ha}^{-1}$ during both the years. Higher RGR during 0-30 DAT might be due to timely and adequate amount of nitrogen supplied during initial crop growth period (Sathiya and Ramesh, 2009). At subsequent growth intervals, there was no significant difference of relative growth rate among nitrogen management practices during both the years of study.

\section{Net assimilation rate}

NAR is the physiological potential for converting the total dry matter into grain yield. The NAR is used as a measure of the rate of photosynthesis minus respiration losses (Sun et al., 1999). NAR was high between 0-30 DAT and decreased rapidly between 60 and 90 DAT and this continued to decrease towards harvest. Among irrigation regimes, there was no significant difference in relative growth rate between 0-30 DAT and 90 DAT- harvest during both the years and in pooled means. However between 30-60 DAT, recommended submergence of 2 to $5 \mathrm{~cm}$ water level as per crop growth $\operatorname{stage}\left(\mathrm{I}_{1}\right)$ recorded significantly higher net assimilation rate but it was at par with AWD irrigation of $5 \mathrm{~cm}$ when water level drops to $3 \mathrm{~cm}$ in water tube $\left(\mathrm{I}_{2}\right)$, but both the treatments were statistically superior over AWD irrigation of $5 \mathrm{~cm}$ when water level drops to $5 \mathrm{~cm}$ in water tube $\left(\mathrm{I}_{3}\right)$ whereas between 60-90 DAT, recommended submergence of 2 to $5 \mathrm{~cm}$ water level as per crop growth stage $\left(\mathrm{I}_{1}\right)$ recorded significantly higher net assimilation rate over other irrigation treatments (Table 6).

Nitrogen levels did not significantly influence net assimilation rate between 60-90 DAT and 90 DAT- harvest during both the years and in pooled means. However between 0-30 DAT and 30-60 DAT, application of $200 \mathrm{~kg} \mathrm{~N}^{-1}$ recorded significantly higher net assimilation rate which was however on par with $160 \mathrm{~kg} \mathrm{~N}$ $\mathrm{ha}^{-1}$ during both the years and in pooled means.

Based on the research results, it can be concluded that recommended submergence of $2-5 \mathrm{~cm}$ water level as per crop growth stage $\left(\mathrm{I}_{1}\right)$ along with application of $200 \mathrm{~kg} \mathrm{~N} \mathrm{ha}^{-1}$ recorded significantly higher physiological growth parameters like leaf area, leaf area index, leaf area duration, crop growth rate, relative growth rate and net assimilation rate 
which was however on par with AWD irrigation of $5 \mathrm{~cm}$ when water level falls below $3 \mathrm{~cm}$ from soil surface in perforated pipe $\left(\mathrm{I}_{2}\right)$ and application of $160 \mathrm{~kg} \mathrm{~N} \mathrm{ha}^{-1}$.

\section{References}

Anil, K., Yakadri, M and Jayasree, G. 2014. Influence of nitrogen levels and times of application on growth parameters of aerobic rice. International Journal of Plant, Animal and Environmental Sciences. 4(3): 231-234.

Bouman, B.A.M and Tuong, T.P. 2001. Field water management to save water and increase its productivity in irrigated lowland rice. Agricultural Water Management. 49: 11-30.

Buresh, R.J., Haefele, S.M. 2010. Changes in paddy soils under transition to water saving and diversified cropping systems. In: Paper to be presented at World Congress of Soil Science, Brisbane, Australia, 1-6 August 2010.

Cassman, K.G., Dobermann, A and Walters, D.T. 2002. Agroecosystems, nitrogen use efficiency and nitrogen management. Ambio. Journal of Human Environment. 31: 132-140.

Chowdhury, M.R., Vinod Kumar, Abdus Sattar and Koushik Brahmachari. 2014. Studies on the Water Use Efficiency and Nutrient Uptake by Rice under System of Intensification. The Bioscan. 9(1): 85-88.

Datta, S.K.D. 1981. Principles and practices of rice production. IRRI. Las Banos, Philippines. 618.

Fageria, N.K., Baligar, V.C and Clark, R.B. 2006. Photosynthesis and crop yield. In Physiology of Crop Production. 95-116, Food Products Press, New York.

Ghosh, M., Swain, D.K., Jha, M.K and Tewari, V.K. 2014. Precision nitrogen management using chlorophyll meter for improving growth, productivity and
$\mathrm{N}$ use efficiency of rice in subtropical climate. Journal of Agricultural Sciences. 5(2): 253-266.

Gomez, K.A and Gomez, A.A. 1984. Statistical procedures for agricultural research. A Wiley inter science publication, John. Wiley and Sons, New York. p: 680.

Huang, D.F., Xi, L.L., Wang, Z.Q., Liu, L.J and Yang, J.C. 2008. Effects of irrigation regimes during grain filling on grain quality and the concentration and distribution of cadmium in different organs of rice. Acta Agronomy Science. 34: 456-464.

Hunt, R. 1978. Plant growth analysis studies on biology. 96 Edward Arnold Publishers Ltd., London. 8-38.

Hunt, R. 1980. Plant growth curves. The functional approaches to plant growth analysis. Edward Arnold Publishers limited, London.

Jayanthi, T., Gali, S.K., Chimmad, V.P and Angadi, V.V. 2007. Leaf colour chart based $\mathrm{N}$ management on yield, harvest index and partial factor productivity of rainfed rice. Karnataka Journal of Agricultural Sciences. 20(2): 405-406.

Kumar, S., Singh, R.S and Kumar, K. 2014. Yield and nutrient uptake of transplanted rice (Oryza sativa) with different moisture regimes and integrated nutrient supply. Current Advances in Agricultural Sciences. 6(1): 64-66.

Kumar, S., Singh, R.S., Yadav, L and Kumar, K. 2013. Effect of moisture regime and integrated nutrient supply on growth, yield and economics of transplanted rice. Oryza. 50(2): 189-191.

Sandhu, S.S., Mahalb, S.S., Vashist, K.K., Buttar, G.S., Brar, A.S and Maninder Singh. 2012. Crop and water productivity of bed transplanted rice as influenced by various levels of nitrogen and irrigation in northwest India. 
Agricultural Water Management. 104: 32-39.

Sathiya, K and Ramesh, T. 2009. Effect of split application of nitrogen on growth and yield of aerobic rice. Asian Journal of Experimental Sciences. 23(1): 303306.

Singh, C.B., Aujla, T.S., Sandhu, B.S and Khera, K.L. 1996. Effect of transplanting date and irrigation regime on growth, yield and water use in rice (Oryza sativa) in northern India. Indian Journal of Agriculture Science. 66(3): 137-141.

Statistical Year Book, Directorate of Economics and Statistics, Government of Telangana. 2017.

Watson, D.J. 1952. Physiological basis of variation in yield. Advances in
Agronomy. 4: 52-69.

Watson, D.J. 1958. The dependence of net assimilation rate on leaf area index. Years. Annals of Botany. 22:37-54.

Williams, R. F. 1946. Physiological ontogeny in plants and its relation to nutrition.VI. Analysis of the unit leaf rate. Australian Journal of Experiment on Biology and Medical Science. 17: 123-332

Wopereis, M.C.S., Kropff, M.J., Maligaya, A.R and Tuong, T.P. 1996. Drought stress responses of two lowland rice cultivars to soil water status. Field Crops Research. 46:21-39.

www.ricestat.irri.org

Yoshida, S. 1981. Fundamentals of rice crop science. International Rice Research Institute. Los Banos, Philippines.

\section{How to cite this article:}

Sridhar, K., A. Srinivas, K. Avil Kumar, T. Ramprakash and Raghuveer Rao, P. 2019. Physiological Growth Parameters of Rabi Rice (Oryza sativa L.) under Alternate Wetting and Drying Irrigation with Varied Nitrogen Levels. Int.J.Curr.Microbiol.App.Sci. 8(01): 1-15. doi: https://doi.org/10.20546/ijcmas.2019.801.001 